\title{
Verb Phrase and Its Translations Found in the Novel "Budha, a Story of Enlightenment"
}

\author{
I Made Juliarta \\ Madejuliarta330@gmail.com \\ English Department, Bali Dwipa University, Denpasar-Bali, Indonesia
}

Received: 03 August 2020 Accepted: 26 November 2020

DOI: $10.24256 /$ ideas.v8i2.1520

\begin{abstract}
This study aims at analyzing the syntactic structure of the verb phrase and its translation process occurred. This study also analyzes the kinds of shifts of verb phrase occurred in the translation process from English into Indonesia. This study is a descriptive qualitative study. The theory used in analyzing data is the theory proposed by Catford and Radford (1988). The theory used in analyzing the data source is the theory in translation especially in shifts of translation and the theory in syntax in order to analyze the verb phrases found in the data source. There are 12 verb phrases as data of this study. The verb in the data source can be categorized as an Indonesian verb. It can be seen from the text that is available in the data source, that the verb phrase in the source language can be transferred into an Indonesian verb in the target language Then, there are some steps applied in this study, the first step of this research is to collect the data source found in the novel The Budha, a Story of Enlightenment. The second step is to read and identify the text in the novel The Budha, a Story of Enlightenment containing the verb phrase. The next step is to take some texts, analyze and interpret the data, and finally draw a conclusion. The verb phrase found in the novel The Budha, a Story of Enlightenment was identified by the researcher. And this study continued in analyzing the translation process occurred. The result of translation analysis of the text shows that there is a shift occurred in all the 12 processes of translating English verb phrase into Indonesian. 8 are classified as changing into lower rank and 4 are classified as changing into a higher rank.
\end{abstract}

Keywords: prepositional phrase; systemic structure; translation shifts; verb phrase. 


\section{Introduction}

Translation can be meant as the process of changing speech of writing from source language into target language. In the process of transferring the meaning, the form may be changed but the meaning is preserved. The form of language refers to the phrases, clauses, sentences, paragraph, and so on, which are spoken or written. Translation is stated as the process of transferring an idea or purpose from source language into target language. The source language form can be replaced by the form of the receptor of target language. The language that is translated is called as the source language. However, the translator must have expert knowledge of both the source language and the target language. Moreover, Nida and Taber (1974: 12) stated that translating consists of reproducing in the receptor language of the closest natural equivalent of the source language or message. It is stated that the first in terms of meaning, and secondly is in terms of style. In the process of reproducing the message, there is a good relationship between source language and target language that must be equivalent. In terms of the rank, Catford (1965:25) stated that this type is categorized into three distinctions, those are: free translation, word-for word translation, and literal translation. In free translation, it is always unbounded-equivalences and tends to be at the higher rank between target units than the sentences. In literal translation, the translator needs to transfer the source language grammatical constructions into the nearest target language equivalents.

This study analyzes the translation process especially in translating the verb phrase found in the novel Budha, a Story of Enlightenment. This novel is chosen as the data source because there are some sentences containing verb phrase found in this data. Moreover, this novel is one of popular novels with the best-selling author. Verb phrase is stated as a syntactic unit that consists of auxiliary or helping verb preceding the main verb. In verb phrase, there are a head verb, complements, and objects. A verb phrase can be meant as a syntactic unit composing of at least one verb. Moreover, Carnie (2007:72) stated that the Verb Phrase is one of the categories that are headed by the Verb. VP should consist minimally of a single verb. The verb can function as the headword of the phrase. Verb phrase contains a verb that is followed by other constituents. Syntax has important role in describing the relationship between the meaning of a particular group of words and word's arrangement. Syntactic analysis has the function to analyze the sentence units, elements of sentences structures, and the class of word. Verb phrase contains a main verb preceded by a maximum of four auxiliary verbs. Auxiliary verb is stated as the verb that comes before the main verb. The verb phrase can be analyzed by the three diagrams that are constructed by the X-Bar theory. The writer used the data sources both from primarily and secondary data in analyzing the verb phrase found in the novel The Budha, a Story of Enlightenment. The verbal complements and adjunct can be generated in two different phrases structures rules. Languages can contain non-lexical of functional categories. There are determiner, auxiliary 
ISSN 2338-4778 (Print) ISSN 2548-4192 (Online) verb, conjunction and degree words. Auxiliary verb includes modal, such as will, can, shall. Example of non-modal is be, have. Verb phrase can be headed by the verb. It's minimally that verb phrase consists of single verb.

There are two results studies investigating the issue in the verb phrase and their translations. The studies that are reviewed here related to the verb phrase and the topic discussed here. The first article that is reviewed entitled "Contrastive Analysis of Verb Phrase in English and Balinese Language Basic Sentences". It can be seen from the article that was written by Budasi (2012) published on jurnal prasi, Undiksha University. The study focused on different sub-sections of verb phrase, they are: basic sentences containing VP, VP in positive sentences, VP in negative sentences, and VP in interrogative sentences. This stated stated that the first data taken will be English for whose basic rules are already set up. In general, a basic sentence in English can be formulated as NP+VP because all English sentences can contain a VP. The strength of this research is on the application on the translation equivalence on the data. This study analyzes the data in the translation process in Balinese Language. The writer chose this research as one of the review because it relates to the topic that was discussed by the researcher especially about verb phrase. There are the differences between this study and the article taken from Budasi (2012). in an article entitled "Contrastive Analysis of Verb Phrase in English and Balinese Language Basic Sentences", the study focuses on the analysis on English verb phrase and balinese language . Meanwhile, in this study, it just analyzes on English verb phrase and translation occured in the translation process. However, article from Budasi (2012) and this study discusses about verb phrase. The writer chose this article as a review as it also discusses about Engllish verb Phrase.

Moreover, Setyaningsih (2013) in her research entitled "A Translation Shift Analysis on Verb and Verbal Phrase of the Avangers Movie and its Subtitling". This study analyze about the category, level shift and the findings of translation shift of verb and verb phrase found in the Avengers movie and its subtitling. This study stated that there are two types of translation shift which are found in the Avengers movie and its subtitling, i.e. category and level shift. It is stated that from 972 data, there are 445 data that have shifted both verbs and verb phrases. There the differences between research entitled "A Translation Shift Analysis on Verb and Verbal Phrase of the Avangers Movie and its Subtitling" and this study. This study focuses on discussing verb phrase and analyzing the translation shift occured in the translation process, meanwhile the study from Setyaningsih (2013) focuses on the translation and its subtitling. The writer chose this study as a research review because the study from Setyaningsih (2013) also discussed more in verb phrases.

\section{Method}

In analyzing the verb phrase found in the novel The Budha, a Story of Enlightenment, the writer used the data source both primary and secondary. Arikunto (2010:22) stated that primary data source is stated as the data in the verbal form or word that is spoken, gesture or attitude that is done by the trustworthy subject. In supporting 


\section{Made Juliarta}

Verb Phrase and its Translations Found in the Novel "Budha, a Story of Enlightenment"

the data, several references were used by the writer. Several sources related to syntax, phrase, constituent, and construction were used in supporting primary data. Documentation is used by the writer as the method of collecting data. Arikunto (2010:22) stated that a documentation method can be meant as finding data using book, transcript, agenda, and the others. The first step is to collect the data source found in the novel The Budha, a Story of Enlightenment. The second step is to read and identify the text in the novel The Budha, a Story of Enlightenment containing the verb phrase. The next step is to take some texts, analyze and interpret the data, and finally draw conclusion. The verb phrase found in the novel The Budha, a Story of Enlightenment was identified by the researcher. And this study continued in analyzing the translation process occurred.

\section{Results}

Text I

The dream had sustained her in the terrifying trip through the forest and the pain of her labor. (20)

Mimpi yang pernah ia alami, membuatnya bertahan dalam perjalanan menakutkan melewati hutan, juga saat ia menderita kesakitan waktu melahirkan. (22)

It can be seen from the translation process occurred in text I that, had sustained is

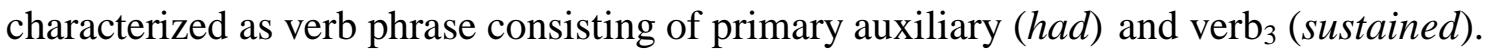
Had sustained is stated as verb phrase because it consists of primary auxiliary (had) and verb $_{3}$ (sustained) as the head word. English verb phrase had sustained is translated into an Indonesian word alami.

We have seen that the translation analysis which occurred in text above that there is a shift occurred from a phrase into a word in the translation process occurred. A phrase the dream is translated into Indonesian word mimpi. The theory that is used by Catford stated that this type of translation shift is stated as a unit shift involving a change in lower rank. A unit shift occurs when the translation equivalent of a source text unit at one rank. Unit shift can be meant as the change in rank, that is, the departure from formal correspondence in which the translation equivalent of a unit at one rank in the source language. This type of shift is stated as unit shift, that is, a change in lower rank that is translating a phrase the dream into an Indonesian word mimpi.

\section{Text II}

That morning the queen had awakened at dawn in case her husband returned early. (18) Hari itu sang ratu bangun subuh-subuh, siapa tahu saja suaminya pulang awal. (18)

It can be seen from text I, that English verb phrase had awakened consists of 
primary auxiliary verb had and followed by $\operatorname{verb}_{3}$ awakened. Had awakened is categorized as verb phrase since it consists of primary auxiliary (had) and verb 3 (awakened) as head work. English verb phrase had awakened is translated into Indonesian verb bangun. The verb bangun is categorized as Indonesian verb. It can be seen from the text $\mathrm{I}$, that the verb phrase in the source language is transferred into an Indonesian verb in the target language. We can see from the translation in text I that there is a shift occurred from a verb phrase into an Indonesian verb in the translation process occurred. A verb phrase had awakened is translated into a verb bangun. Theory proposed by Catford stated that this type of translation shift is stated as a unit shift involving a change in lower rank. A Unit shift occurs when the translation equivalent of a source text unit at one rank. Unit shift can be meant as the change in rank, that is, the departure from formal correspondence in which the translation equivalent of a unit at one rank in the source language. This type of shift is stated as unit shift, that is, a change in lower rank that is translating a verb phrase had awakened into an Indonesian verb phrase bangun.

\section{Text III}

Her mood had changed. (17)

Suasana hatinya sudah berubah. (17)

It can be seen from verb phrase in text II that English verb phrase had changed consists of primary auxiliary verb had and followed by verb ${ }_{3}$ changed. Had changed is categorized as verb phrase since it consists of primary auxiliary (had) and verb 3 (changed) as the head work. English verb phrase had changed is translated into indonesian verb sudah berubah. The verb phrase sudah berubah is categorized as Indonesian verb phrase. It can be seen from the text II, that the verb phrase in the source language is transferred into an Indonesian verb phrase in the target language.

We can see from the translation in text II that there is a shift occurred from a word into an Indonesian phrase in the translation process occurred. A word mood is translated into Indonesian phrase suasana hati. Theory that is proposed by Catford stated that this type of translation shift is stated as a unit shift involving a change in higher rank. A Unit shift occurs when the translation equivalent of a source text unit at one rank. Unit shift can be meant as the change in rank, that is, the departure from formal correspondence in which the translation equivalent of a unit at one rank in the source language. This type of shift is stated as unit shift, that is, a change in higher rank that is translating a word mood into an Indonesian phrase suasana hati.

\section{Text IV}

Maya's premonition had told her that this birth would be sacred. (16)

Firasat Maya mengatakan kelahiran anaknya adalah sesuatu yang sakral. (15) 
We can see from English verb phrase in text III, that English verb phrase had told is consisted of primary auxiliary verb had and followed by verb ${ }_{3}$ told. Had told is stated as

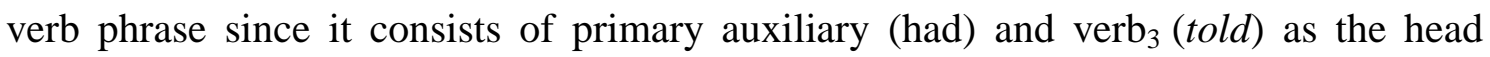
word. English verb phrase had told is translated into an Indonesian verb mengatakan. The verb mengatakan is categorized as an Indonesian verb. It can be seen from the text III, that the verb phrase in the source language is transferred into an Indonesian verb phrase in the target language.

It can be seen from the translation in text III that there is a shift occurred from a verb phrase into an Indonesian verb in the translation process occurred. A verb phrase had told is translated into Indonesian verb mengatakan. Theory that was proposed by Catford stated that this type of translation shift can be meant as a unit shift involving a change in lower rank. A Unit shift occurs when the translation equivalent of a source text unit at one rank. Unit shift can be meant as the change in rank, that is, the departure from formal correspondence in which the translation equivalent of a unit at one rank in the source language. This type of shift is stated as unit shift, that is, a change in lower rank that is translating a verb phrase had told into an Indonesian verb mengatakan.

\section{Text V}

Balgangadhar had found a sheltered place beside the trail, and the royal palanquin arrived there only moments before Maya went into the final stages of labor. (16)

Balgangadhar menemukan tempat teduh di samping jalan setapak yang mereka lalui, tandu kerajaan tiba di tempat itu hanya beberapa saat sebelum Maya melewati tahap-tahap akhir menjelang kelahiran anaknya. (15)

It can be seen from the translation process occurred in text IV, had found is characterized as verb phrase consisting of primary auxiliary ( $h a d)$ and verb v $_{3}$ found). Had found is stated as verb phrase because it consists of primary auxiliary (had) and verb ${ }^{3}$ (found) as the head word. English verb phrase had found is translated into an Indonesian verb menemukan. The verb menemukan is categorized as an Indonesian verb. It can be seen from the text IV, that the verb phrase in the source language is transferred into an Indonesian verb menemukan in the target language.

From the translation analysis occurred in text IV that there is a shift occurred from a verb phrase into an Indonesian verb in the translation process occurred. A verb phrase had found is translated into Indonesian verb menemukan. The theory that was used by Catford stated that this type of translation shift can be meant as a unit shift involving a change in lower rank. A Unit shift can occur when the translation equivalent of a source text unit at one rank. Unit shift can be meant as the change in rank, that is, the departure from formal correspondence in which the translation equivalent of a unit at one rank in the source language. This type of shift is stated as unit shift, that is, a change in lower rank that is translating a verb phrase had found into an Indonesian verb menemukan.

Text VI 
Sitting up, Maya immediately recognized her visitors for what they were devas, or celestial beings. (18)

Maya duduk dan langsung mengenali ketiganya, mereka para deva, makhluk surgawi.

It can be seen from the text $\mathrm{V}$, that immediately recognized can be categorized as the verb phrase. The verb recognized is stated as the head of the VP. In this case, it is modified by the ADVP immediately. It can be seen that ADVP stands as the pre-modifier of the VP. The construction of VP immediately recognized in text $\mathrm{V}$ can be seen as follows: V" (ADVP + V' (V)).

From the translation analysis occurred in text $\mathrm{V}$ above that there is a shift occurred from a translation process in translating a phrase her visitors into a word ketiganya. A phrase her visitors is translated into Indonesian word ketiganya. The theory that is used by Catford stated that this type of translation shift can be meant as a unit shift involving a change in lower rank. A Unit shift can occur when the translation equivalent of a source text unit at one rank. Unit shift is the change in rank, that is, the departure from formal correspondence in which the translation equivalent of a unit at one rank in the source language. This type of shift is stated as unit shift, that is, a change in lower rank that is translating a phrase her visitors into an Indonesian word ketiganya.

\section{Text VII}

Embarrassed and confused, Maya quickly pulled her robe together again with one hand. (17)

Malu dan bingung, Maya cepat-cepat merapatkan jubahnya lagi dengan satu tangan.

It can be seen from the text VI, that quickly pulled is categorized as the verb phrase. The verb pulled is stated as the head of the VP. In this case, it is modified by the ADVP quickly. It can be seen in text VI, that ADVP stands as the pre-modifier of the VP. The construction of VP quickly pulled in text VI can be seen as follows: V" (ADVP + V' (V)). According to Carnie (2007:72), the Verb Phrase is one of the categories that are headed by the Verb. VP consists minimally of a single verb. The verb can function as the headword of the phrase.

From the translation analysis which occurred in text VI stating that there is a shift occurred from a translation process in translating a word quickly into a phrase cepat-cepat. A quickly is translated into Indonesian phrase cepat-cepat. The theory that is used by Catford stated that this type of translation shift can be meant as a unit shift involving a change in higher rank. A Unit shift can occur when the translation equivalent of a source text unit at one rank. Unit shift is the change in rank, that is, the departure from formal correspondence in which the translation equivalent of a unit at one rank in the source language. This type of shift is stated as unit shift, that is, a change 
in lower rank that is translating a word quickly into an Indonesian phrase cepat-cepat.

\section{Tex VIII}

The queen lay quietly on the ground, almost listless. (16)

Sang ratu terbaring lemas di tanah, hampir tak bertenaga. (15)

It can be seen from the text VII, that lay quietly is categorized as the verb phrase. The verb lay is stated as the head of the VP. In this case, it is modified by the ADVP quietly. It can be seen that ADVP stands as the pre-modifier of the VP. The construction of VP lay quietly in text V can be seen as follows: V" (ADVP + V' (V)).

From the translation analysis occurred in text VII, that there is a shift occured from a translation process in translating a word listless into a phrase tak bertenaga. A word listless is translated into Indonesian phrase tak bertenaga. The theory that is used by Catford stated that this type of translation shift can be meant as a unit shift involving a change in lower rank. A Unit shift can occur when the translation equivalent of a source text unit at one rank. Unit shift is the change in rank, that is, the departure from formal correspondence in which the translation equivalent of a unit at one rank in the source language. This type of shift is stated as unit shift, that is, a change in higher rank that is translating a word listless into an Indonesian phrase tak bertenaga.

\section{Text IX}

She expressly wanted to visit the sacred grove because a huge tree stood there like a pillar to the mother goddess. (16)

Ia ingin cepat-cepat berada di hutan keramat karena di sana ada pohon besar yang menjulang bagaikan pilar bagi ibu bumi. (15)

It can be seen from the text VIII, that expressly wanted to visit is categorized as the verb phrase. The verb wanted is stated as the head of the VP. In this case, it is modified by the ADVP expressly. It can be seen in text VIII, that ADVP stands as the pre-modifier of the VP. The construction of VP expressly wanted to visit in text VIII can be seen as follows: V" (ADVP + V' (V)). Carnie (2007:72) stated that, the Verb Phrase is one of the categories that are headed by the Verb. VP consists minimally of a single verb. The verb can function as the headword of the phrase. The verb phrase consists of

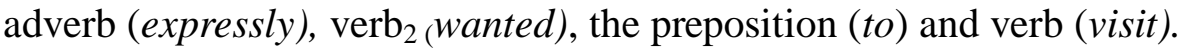

From the translation analysis occurred in text VIII, that there is a shift occured from a translation process in translating a word expressly into a phrase cepat-cepat. An adverb expressly is translated into Indonesian phrase cepat-cepat. The theory that is used by Catford stated that this type of translation shift can be meant as a unit shift involving a change in higher rank. A Unit shift can occur when the translation equivalent of a source text unit at one rank. Unit shift is the change in rank, that is, the departure from formal correspondence in which the translation equivalent of a unit at one rank in the source language. This type of shift can be stated as unit shift, that is, a 
change in lower rank that is translating a word expressly into an Indonesian phrase cepat-cepat.

It can also be seen in text VIII, that phrase a huge tree is translated into pohon besar. The structure shift that is occurred in the translation process of a huge tree into pohon besar as there is a change of the position of word structure in both languages without changing the meaning of the message in the source text. A huge tree in the source language in text VIII is translated into rumah besar in the target language. It can be seen from the translation process in a huge tree that is constructed by modifier (adjective, $a$ huge) + head (noun tree) and translated into head (noun pohon) + modifier (adjective, besar). According to Catford (1985) stating that structure shift is the change grammatically between the structure of the source language and target language.

\section{Text X}

As he gently placed Maya's arm across her chest, Suddhodana shuddered. (27)

Ketika Suddhodana dengan lembut menyilangkan tangan Maya di dada, ia gemetar. (32)

We can see from the text IX, that gently placed is categorized as the verb phrase. It can be seen that the verb placed is stated as the head of the VP. In this case, it is modified by the ADVP gently. It can be seen in text IX, that ADVP stands as the pre-modifier of the VP. The construction of VP gently placed in text IX can be seen as follows: V" (ADVP + V' (V)). According to Carnie (2007:72), the Verb Phrase is one of the categories that are headed by the Verb. VP consists minimally of a single verb. The verb functions as the headword of the phrase.

From the translation analysis occurred in text IX, that there is a shift occurred from a translation process in translating an adverb of manner gently into a phrase dengan lembut. An adverb gently is translated into Indonesian phrase dengan lembut. The theory that is used by Catford stated that this type of translation shift is a unit shift involving a change in higher rank. A Unit shift occurred when the translation equivalent of a source text unit at one rank. Unit shift is the change in rank, that is, the departure from formal correspondence in which the translation equivalent of a unit at one rank in the source language. This type of shift is stated as unit shift, that is, a change in higher rank that is translating an adverb of manner gently into an Indonesian phrase dengan lembut.

\section{Text XI}

Suddhodana rode slowly before them, ignoring the strife only a short distance away (13)

Suddhodana berkuda pelan-pelan di depan mereka, tidak mengacuhkan pertempuran yang berlangsung tak jauh dari situ. (11) 
The translation process which occurred in text $\mathrm{X}$ showed that rode slowly is categorized as the verb phrase. The verb rode is stated as the head of the VP. In this case, it is modified by the ADVP slowly. It can be seen that ADVP stands as the pre-modifier of the VP. The construction of VP rode slowly in text $\mathrm{X}$ can be seen as follows: V" (ADVP + V' (V)).

From the translation analysis which occurred in text $\mathrm{X}$, stating that there is a shift occurred from a translation process in translating an adverb of manner slowly into a phrase pelan-pelan. Slowly is translated into Indonesian phrase pelan-pelan. The theory that is used by Catford stated that this type of translation shift is a unit shift involving a change in higher rank. A Unit shift occurred when the translation equivalent of a source text unit at one rank. Unit shift is stated as the change in rank, that is, the departure from formal correspondence in which the translation equivalent of a unit at one rank in the source language. This type of shift is stated as unit shift, that is, a change in higher rank that is translating an adverb of manner slowly into an Indonesian phrase pelan-pelan.

\section{Text XII}

After dinner Suddhodana had retired to the nursery to be alone with his son. (26) Setelah makan malam Suddhodana pergi ke kamar bayi untuk menghabiskan waktu bersama putranya. (30)

We have seen the translation process occurred in text XI, had retired is characterized

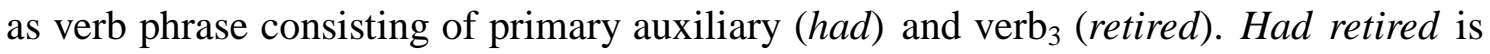

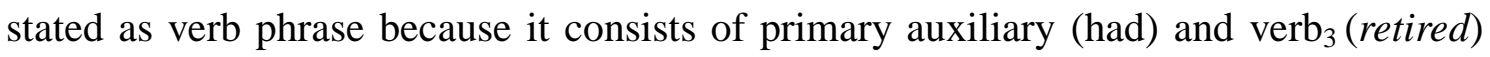
as the head word. English verb phrase had retired is translated into an Indonesian verb pergi. The verb pergi is categorized as an Indonesian verb. It can be seen from the text $\mathrm{XI}$, that the verb phrase had retired in the source language is transferred into an Indonesian verb pergi in the target language.

From the translation analysis occurred in text XI that there is a shift which occurred from a verb phrase into an Indonesian verb in the translation process occurred. A verb phrase had retired is translated into Indonesian verb pergi. The theory used by Catford stated that this type of translation shift can be meant as a unit shift involving a change in lower rank. A Unit shift occurs when the translation equivalent of a source text unit at one rank. Unit shift can be meant as the change in rank, that is, the departure from formal correspondence in which the translation equivalent of a unit at one rank in the source language. This type of shift is stated as unit shift, that is, a change in lower rank that is translating a verb phrase had retired into an Indonesian verb pergi.

Based on the result of translation analysis of the text shows that there is a shift occurred in all the 12 process of translating English verb phrase into Indonesian. 8 are classified as changing into lower rank and 4 are classified as changing into higher rank. 


\section{Discussion}

This study describes the types of shifts of verb phrase occurred in the translation of The Budha, a Story of Enlightenment. In analyzing the translation process, this study used the theory of shift translation that is proposed by Catford (1965). The result of translation analysis of the text shows that there is a shift occurred in all the 12 process of translating English verb phrase into Indonesian. 8 are classified as changing into lower rank and 4 are classified as changing into higher rank.

According to Catford (1965), shift can be meant as the departure from formal correspondence in the process from the SL into the TL. The translation shift can be done in order to get the natural equivalent of the source text message into the target text (1965: 76). Moreover, Catford (1965) stated that it divides the shift in translation into two major types, those are: level/rank shift and category shift. Level/rank shift can refer to a source language item at one linguistic level that has a target language translation equivalent at a different level. It is stated as a shift process from grammar into lexis. Category shift is stated as the departures from formal correspondence in translation category in the source language system. Catford (1965) stated that there are two types of shift, those are: (1) Shift of level and (2) shift of category. In the level of shift, Catford (1965) stated that cases of shifts from grammar to lexis are quite frequent in translation process between languages. He stated that level/rank shift refers to a source language item at one linguistic level that has a target language translation equivalent at a different level. It is important to conduct this study in order to figure out the translation process of verb phrase found in novel The Budha, a Story of Enlightenment. This study describes the types of shifts of verb phrase occurred in the translation of The Budha, a Story of Enlightenment. It is interesting to conduct shift translation research in order to know that shifts sometimes occur in translation process of verb phrase from English into Indonesian. Category shift can be meant or stated as the departures from formal correspondence in process of translation. The part of category shift is structure shifts, class shifts, unit shift, and intra-system shifts. Structure shift is stated as the changing of words sequence in a sentence. It is stated that sstructure of shifts can occur in phonological, graph logical translation and in total translation. Structure shifts can happen at all ranks. We can see the sstructures of shifts at other ranks. In the structure shifts, it can be found at other ranks, for example that it can be seen at group rank. It can be seen for example that in translating a shift from modifier and head translated into modifier, head and a qualifier. Meanwhile in class shift, it is stated that members groups a given unit is defined by operation in the structure of unit. Class shift can occur when the translation equivalent of source language is a member of different class from the original item. It can be seen at group rank. According to Catford (1965), there is often a shift from MH (modifier + head) to (M) HQ ((modifier+) head + qualifier) in translation. This study also used the theory of class-shift stating that it can occur when the translation equivalent of a SL item that is a member of a different class from the original item. In the intra-system shift, it refers to the shifts occurring internally in the system. It is stated that 


\section{Made Juliarta}

Verb Phrase and its Translations Found in the Novel "Budha, a Story of Enlightenment"

Intra-system shifts can occur when a term is singular in the source language and its textual equivalent is plural. Unit shift is stated as the changes of rank, that is, departures from formal correspondence in which the translation equivalent of a unit at one rank in the source language is a unit at a different rank in the target language. Unit shifts is the shifts from morpheme to word, word to phrase, clause to sentence. Intra-system shift is stated as the shifts that occur internally, in the system. This used is for those cases where the source and the target language possess systems when translation involves selection of a non-corresponding term in the target language system. Intra-system shifts can occur when a term is singular in the source language and its textual equivalent is stated as plural form. Translation shift can occur in the lexico grammar and at the thematic level of the text. In structure shift, we can see that there are two languages that have different element of structure. It is stated that in the shift of level, a source language at one linguistic level has a target language that is equivalent at a different level. There is also a change in rank or it is called as unit-shifts. However, it does not mean that the changes of the type of shift can occur in the translation. We often see that there is structure change that is more often than rank-changes. In the category shift, it is stated that there are departures from formal correspondence in the translation process. It can be seen that category shift can be stated as the departures from formal correspondence in translation process. It is stated in the theory that grammatical category in the target language can be said to occupy the same position in the system of the target language as the given source language category in the source language system. The category of shift can be divided again into some parts, those are: structure shifts, class shifts, unit shift, and intra-system shifts. Structure shift is the changing of words sequence in a sentence. In the intra-system shift, it can be seen that it refers to the shifts that occurs internally, within the system; that is for those cases where the source and the target language can possess systems which approximately correspond formally as to their constitution, but when translation involves selection of a non-corresponding term in the target language system. Intra-system shifts can occur when a term is stated as singular in the source language and its textual equivalent is plural. It can be seen that the types of shift are also discussed in this research. The writer chose this theory in analyzing the data as this theory gives clear explanation about the types of shift that occurred in Indonesian translation into English. Meanwhile, the data in this study are presented by using the formal method. This study used the theory that is proposed by the theory of Sudaryanto (1993) stating that it deals with the way of presenting a topic by applying explanation using words to describe findings. It can be seen that the formal method can be meant that the data were analyzed using symbols, tables, diagrams, and figures.

There is another study related the findings of this study namely entitled "the relationship between noun phrase and verb phrase written by Sarage (2014). This paper discusses a noun phrase and a verb phrase as the main part of a sentence. There are some special characteristics of the noun phrase and the verb phrase that are discussed. This article tries to see if other sentence elements such as an adjectival, adverbial, and prepositional phrases can emphasize in a sentence. The similarity between an article written by Sarage (2014) and this study is analyzing English verb phrase. The difference 
is that this study analyzes about the translation process, meanwhile an article written by Sarage (2014) analyzes syntactic structure on an English verb phrase in a sentence

\section{Conclusion}

The writer concludes that there is a shift occurred in all the 12 process of translating English verb phrase into Indonesian. 8 are classified as changing into lower rank and 4 are classified as changing into higher rank. For further research, it is suggested to find the intended meaning when translating English verb phrase into Indonesian translation. In analyzing the translations process, it is better to use the theory related to the verb phrase and translation. Further research is invited to analyze more the translation process in translating English verb phrase, then it can describe the translation process occured. In analyzing the translation of verb phrase for further research, it is also better to use mapping theory in analyzing the translation process.

\section{Acknowledgement}

I would like to express my gratitude to the Almighty God, who has given me blessing and guidance in finishing this study entitled verb phrase and its translation found in the novel "Budha, a story of enlightenment. Moreover, I would also like to express my big thanks to my relatives and friends from English Department, Bali Dwipa University for their meaningful support. Finally, I would like to say a massive thanks to those who voluntarily participated in this article. This study would not have been completed without a support from them.

\section{References}

Ayu, M.N. (2016). A Translation Analysis on Verb Phrase "The Giver" Novel by Lois Lowry. A Thesis S1, Surakarta: Department of English and Education Muhammadiyah University of Surakarta.

Broccias C. (2011). Motivating the Flexibility of Oriented -ly Adverbs". Dis. (serial online), Jan-Mar, (cited 2011 Jun. 56. Available from URL: http:/www.benjamins.com/gov/ncidod/EID/eid.htm

Chaer, A. (2011). Tata Bahasa Praktis Bahasa Indonesia. Jakarta: Rineka Cipta.

Fabb, N. (2005). Sentence Structure. New York: Routledge.

Gelderen, E. V. (2010) An Introduction to English Grammar, Amsterdam, John Benjamin Publication.

Julmand, Lise-L and Helge S. (2012). A Concise Contrastive Grammar of English for Danish Student, Denmark: Narayana Press

Kartawinata, H. (2010). Contrastive Analysis of Verb Phrases in English and Tetun Language Basic Sentences. In Issues in English a Foreign Language and Sociolinguistics VO I: 10-20. Malang: Ma Chung Press.

Massoum, S. M. H. and Azadeg S (2014) Translation Shifts in the Persian Translation of a Tale of Two Cities by Charles Dickens, MCSER-CEMAS-Sapienza 
University of Rome, (March), Doi:10.5901/ajis/2013.2n1p391.

Mukti, H. F. (2002). Complete English Grammar. Yogyakarta: Ansolut.

Nababan, Mangatur, (2016) Pengembangan Model Penilaian Kualitas Terjemahan, accessed on January 24, 2016 https:publikasiilmiah.ums.ac.id

Nuryanti. (2007). Adverbs and its Syntactic Function with Special reference to Danielle Steel's Daddy. Denpasar: Udayana University.

Petrus. 2005. The Morphosyntactic Analysis of -ize, -ify, and -en in English. Denpasar: Udayana University.

Tangkelangi, N. (2020). Students' Competence in the TOEFL Structure and Written Expression. IDEAS: Journal on English Language Teaching and Learning, Linguistics and Literature, 8(1). doi:https://doi.org/10.24256/ideas.v8i1.1271

Verspoor, M and Sauter, K. (2000). English Sentence Analysis: An Introductory Course.Amsterdam: John Benjamins Publishing Company.

Yarahmadzehi, N (2013) A Study persian Translation of English Phrasal erbs in Harry Potter and the Order of the Phoenix, Canadian Center of Scient and Education, (January, 2013), accesed on December 24, 2015, http: //www. ccsenet.org/journal/index.php/ijel/article/viewFile24241/15355, 201 